\title{
A tribute to Abdul Raufu Mustapha: living a constructive life ${ }^{1}$
}

\begin{abstract}
Abdul Raufu Mustapha, who died on 8 August 2017, was a Professor of African Politics at the University of Oxford. He will be remembered as a sterling scholar and a committed comrade who devoted his life to leaving the world better than he found it. For Raufu, the purpose of life was the construction of a better society and he had a clear idea of what a better society meant - more equality, more opportunities for all, access to qualitative and critical education and, above all, catering for the needs of all members of society. What was important about his life was that he always believed that a better society was possible and we all have a role in bringing it about.
\end{abstract}

Raufu was a true Nigerian born in Aba in 1954; he was the ninth of nineteen siblings, all of whom are still alive. His father, who is also still alive, is Ishola Mustapha from Ilorin, a retired foreman and mechanic at Niger Motors and United Africa Company, while his mother, Rabia Mustapha, was a trader. He had his primary education in Aba and Kano, secondary education in Sokoto and Ilorin, and went to university in Zaria and Oxford. He was very fluent in Igbo, Hausa and Yoruba languages and felt at home in all parts of the country.

Raufu had the good fortune of being married to a friend and intellectual soulmate, Kate Meagher, originally from Canada and currently an Associate Professor in the Department of International Development of the London School of Economics. They are blessed with two children, Asma'u and Oluseyi. Raufu had exceptional social skills that enabled him to maintain and sustain a vast array of friends, many from his days in primary and secondary schools. He devoted a lot of the one resource he had very little of - time - to contact his friends, visit them, socialize, stay in touch with the evolution of their lives and families, and to generally sustain his network of friends.

Raufu was best known for his scholarship. After his master's at Ahmadu Bello University, he did his $\mathrm{PhD}$ in Politics at Oxford. After his long sojourn as a lecturer in Ahmadu Bello University, he transferred his services to the University of Oxford, where he worked for the rest of his life. He was a committed scholar and was well versed in multidisciplinary approaches and methodologies. He was a towering presence in African academic networks and a valuable member of CODESRIA, the organization that hosts the African social science community. Over the past two years, he invested time and resources to seek the support of the Dangote Foundation to establish a scholarship scheme that would bring more African students to benefit from the academic excellence available at Oxford.

For Raufu, scholarship was the scientific expression of the political values of the researcher. This approach characterized the key themes he engaged with: the promotion of social change on the basis of scientific and critical thought through the pursuit of a progressive agenda that prioritizes the interests of ordinary people; addressing the challenges to social cohesion posed by identity politics - ethnicity

${ }^{1}$ An earlier version of this tribute was published in the Daily Trust, Nigeria.

(C) International African Institute 2020 
and religion in particular; and promoting democratic culture, its values, principles and practices.

Raufu was very much the product of the radical politics that characterized Ahmadu Bello University during the 1970s and 1980s. He was also a leading cadre of the radical movement, and two examples of the role he played are worth citing - in the Movement for a Progressive Nigeria (MPN) and the Zaria Group. Throughout his undergraduate days in Ahmadu Bello University (1974-77), Raufu was one of the leaders of the MPN, the incarnation of the radical Marxist philosophy and praxis that marked the period. Radicalism for Raufu meant breaking the bond between imperialism and the Nigerian (African) state as a precondition for emancipating the people from oppression and exploitation. Central to this approach was an understanding of imperialism as a world system with tentacles in the economy, trade, ideology and politics of affected societies. Throughout the period, he worked tirelessly organizing Marxist study cells, identifying comrades who could be recruited and trained, and, above all, linking the activities of the MPN to the key questions of the time - combating apartheid and the racist regimes of Southern Africa, promoting the just struggles of the Palestinian people, organizing against military dictatorship at home and activating links between the student and trade union movements.

Under his leadership, the MPN became a formidable force in the university, one that was able to influence the leadership of the student union government and the radical agenda that characterized political life on campus - and across campuses, as he also linked up with other radical organizations in other institutions. A considerable part of his time, energy and intellect during his student days was devoted to these issues, which are not reflected in his $\mathrm{CV}$. Raufu also invested considerable talent and commitment in ensuring that good new leadership emerged, which could sustain the movement after his graduation. Immediately after his National Youth Service Programme in Kano, he returned to the university as a graduate assistant to continue the struggle.

Upon graduation, Raufu transited to the Zaria Group, the Marxist movement composed of lecturers and intellectuals that provided leadership for radical thought and praxis as well as links to the larger Nigerian, African and international struggles. The Zaria Group published a journal - Struggle - which, for the purposes of the period, we pretended to be publishing from Ilorin. For years, Raufu would dutifully travel to Ilorin each month to post it to comrades all over the country. The Zaria Group was not the only leftist group in the university. There was another group of radicals that was later to align with the left-wing People's Redemption Party (PRP) that pursued Aminu Kano's pro-talakawa (common people's) struggles. It was a period of intense factionalism and Raufu devoted his time, energy and skills to promoting the 'correct' Marxist-Leninist understanding of the problematic. That story has still not been told, but with more members of the Zaria Group transiting to the next world, it will be useful to tell it soon.

One of the occasions that deepened the internal debate among progressives was the Karl Marx Centenary Anniversary Conference, jointly organized by the various strands of Marxists and Progressives in Zaria in 1983. Raufu presented a thoughtful and incisive critique of the PRP experience, entitled 'Critical notes on the national question: practical politics and the People's Redemption Party'. 
It was a major contribution that provided room to revive the debate on the contending pathways to progressive change.

Raufu's most important commitment was that of addressing the challenges to social cohesion posed by identities - ethnicity and religion in particular. $\mathrm{He}$ took the task of constructing and stabilizing Nigerian federalism seriously, and throughout his career invested his skills in producing a better understanding of ethnicity in Nigeria's political system. In 1986, he published 'The national question and radical politics in Nigeria' in the Review of African Political Economy.

Some of Raufu's most important works were carried out over the past five years and were devoted to promoting a scientific understanding of the Boko Haram insurgency and seeking pathways to peace. Over the period, he worked with around twenty younger researchers from Nigeria, Niger and Europe, producing a corpus of seminal work that was empirically based and theoretically sound. The work addressed Muslim identities, Islamic movements and MuslimChristian relations. The researchers closely examined the factors that promoted Islamist radicalization, the pathways that emerged and the reasons that made Borno the ground zero of the insurgency. They also examined the empirical research question of why Islamist radicalization occurred in Northern Nigeria but not in Southern Niger, which has the same sociological, religious, geographic, linguistic and cultural characteristics.

So far, the research has resulted in three important edited volumes: Sects and Social Disorder: Muslim identities and conflict in Northern Nigeria, published in 2014 (James Currey); and Creed and Grievance: Muslim-Christian relations and conflict resolution in Northern Nigeria, published in 2018 (Boydell and Brewer). Overcoming Boko Haram: Faith, Society and Islamic Radicalization in Northern Nigeria, edited by Raufu and Kate Meagher, was published in 2020 (Boydell and Brewer). The projects on Boko Haram have also produced many policy papers that have been made available for the use of government and security agencies as well as by the community of scholars. Raufu's burning desire over the past few years was the imperative of understanding the insurgency so that we could begin the difficult process of addressing the core issues of poverty, inequality and the crumbling social order, all of which have wreaked havoc on Nigerian society and are dismantling the nation. Ultimately, his concern was the construction of a peaceful, united country with a progressive social system that would address the needs of all its citizens. His numerous relations, friends and comrades will continue to miss Raufu.

Jibrin Ibrahim

Jibrin Ibrahim is the Director of the Centre for Democracy and Development, Abuja, Nigeria. Email: jibo72@yahoo.com 